\title{
ホワイトヘッド手術による後障害の 病態とその治療
}

社会保険中央総合病院大腸肛門病センター

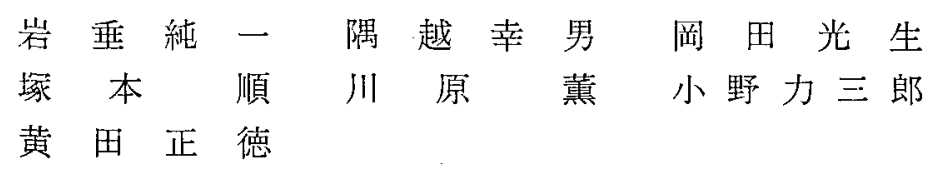

ホワイトヘッド手術の後障害には排ガス, 排便などの知覚異常, 肞門狭窄, そして粘膜脱がある. 排ガス, 排便などの知覚異常は肚門の知覚の場といえる歯状線近傍を切除してしまうため生じる治療のしようのない 後障害である. 肛門狭窄は将核带を環状に切除し粘膜皮䖉縫合した部分に縫合不全の結果肛門に 輪状に配列 された㾿痕が形成され，これが肛門の自由な拉張を妨げるために生じる. 治療は輪状の廄痕の一部を切除し 放射状の開放創とするか皮膚弁移動術を行う. 粘膜脱には将核帯の切除時に皮切を外に扔き過ぎたため生じ たもの，痔核带の切除不充分のため生じたもの，そして肚門支持組織の破壞のため出現してきたものとがあ る. 粘膜脱の範囲が少なければ放射状に切除すればよいし広範国のものなら粘膜脱部を切除後, 粘膜皮䖉縫 合を行い肛囲皮膚に減張切開を加え皮䖉弁を作成しこれを肛門管内一移動させる術式を行う。全周性の粘膜 脱に対しても本術式は効果がある。

索引用語 : 肛門手術後障害，ホワイトヘッド肛門（粘膜脱）

\section{はじめに}

痔核に対するホワイトヘッド手術は瘅核帯を環状に全 周性に切除し直腸粘膜と肚門皮膚とを縫合するといら術 式である.

1882年 Walter Whitehead $か ゙$ Britisch Medical Journal 亿登表 ${ }^{1)}$ し以来，特核に対する根治性があるため 広く行われた術式であった。しかし，かなりの技術を要 する術式であり，未熟に行うと重篤な後障害が生じてし まうこと，また，たとえ上手に行ったにしても手術その ものが将核とともに繊細な肛門を全周性に切除してしま らといった非生理的な侵䠹の大きい術式であるために技 術的に避けようのない後障害が生じることも判明し，欧 米では徐々に行われなくなってきた術式である. 我国で も，その術式の久点が遅まきながらゆきわたり近年では ほとんど行われなくなってきているが，いまだ，その後 障害で悩ませられている患者は少なくない，

本文では，これらホワイトヘッド手術の後障害に対し て, その病態と治療法について我々が行っている術式を 中心に述べる.

\section{ホワイトヘッド手術による後障害の病馝}

ホワイトヘッド手術牥術式自体の煩雑さ，侵襲の大き さ，および，その後障害のために次第に行われなくなっ てきている. しかし，過去に受けたホワイトヘッド手術 のための後障害で現在, 治㙩を必要としている患者は少 なくない.

図1 は昭和57年末までの当センターにおけるホワイト ヘッド手術による後障害のため手術を施行した例数の推

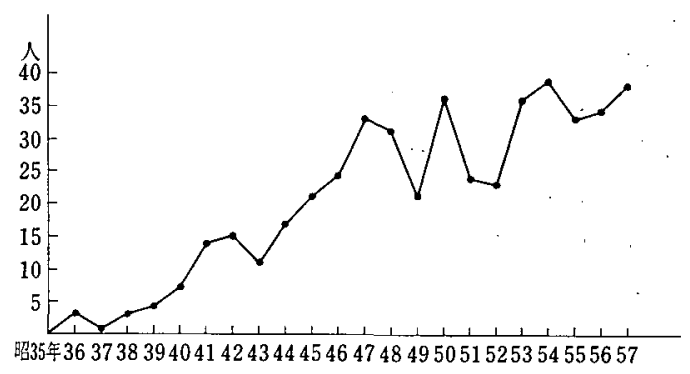

図 1 ホロイトヘッド手術の後障害(手術列) （社保中，1960 1982） 
移をあらわしたものである．図の示すごとく手術例数は 減少しておらず，最近ではむしろ增加傾向にあると言え る. したがって現在のところ，ホワイトヘッド手郝の後 障害を過去の遺物として葬るわけにはいかず，以かに对 応し処置してゅくか今後もしばらくは考えさせられるべ き問題である.

さて，ホワイトヘッド手術の後障害として知られてい るものには，排ガス，排便などの知覚異常，肍門狭窟， そして粘膜脱がある

排ガス，排便などの知党異常は，ホワイトヘッド手術 が肛門の微妙な知覚の場である歯状線近傍を全周性に切 除してしまう結果，生じるといわれている．つまり，歯 状線近傍は trigger zone として知られた脳脊髄神経の 知覚終末組織帯があり，主としてそこで最初に感覚的刺 激を受け排便感が生じるとされている5)，ホワイトヘッ ド手術は，このような部分をすべて破壊してしまうた 的排ガス，排便などの知覚異常が生じてしまうわけであ る.そして，いったん生じた，この後障害は，るはや治 療しようのないものである(2).

肛門狭窄もホワイトヘッド手術の後障害としてよく見 られるものである，狭窄症の発生原因と思われるものに は縫合部の化膿，血腫形成，縫合部が 口側に過ぎる場 合, 粘膜剝離不充分, 術前肛門緊張強などがある ${ }^{3}$ 。縫 合部が口側に過ぎた場合には肛門部に位置する縫合部が 污染による化澧をおこしやすく，縫合不全におちいって も適切な処置を行えないため狭窄が生じるという．要は 痔核帯を環状切除し粘膜皮膚縫合を行った部に血尰形成 や感染などが生じ縫合不全を招こした場合，創治瘾後に 輪状の誐痕が生じてしまらのである。そして，この肛門 管に輪状に配列された㓔痕が肛門の自由な抬張を妨げ肛 門狭寉の原因となると考えられる。

最後に粘膜脱についてであるが，これはホワイトへッ ド手術の後障害のなかで最も重篤で，なおかつ，その治 療も難しいものである. いったん粘膜脱となってしまう と肛門絶えずジメジメとべとつきを生じ不快な感じを 患者に与え，肛門周囲はカユミを伴う肛囲湿疹となり粘 膜脱の部分からは出血もしやすくなるといら特有の症状 を呈するよらになる。(これが，いわゆるホワイトへッ ド肛門と総称される病態である.）このようなホワイト ヘッド手術後に出現してくる粘膜脱にはその発生機序か ら考えて三種類に分けることができる7、まず第一に帱 核帯を環状切除する際に，あまりに皮切を外に拉き過ぎ たため術直後より粘膜皮膚縫合線が肛門外にあり粘膜脱 となってしまったものである.これは手術の失敗といえ る. 第二に将核带を切除する際に低位にて切除したため 切除の不充分であった静脈䇾より再び痔榜を形成し脱出
をおこしてくれるものである。これも手術の失敗といえ る. 第三に手術は技術的に完全に行われたにもかかわら ず長期間，経過の後，粘膜脱が出現してきたもの，つま り本来の意味でのホワイトヘッド粘膜脱といえるもので ある。

以上の発生機序が異なる粘膜脱においてはその症状の 発現する時期も異なってくる. 第一の粘膜脱の場合には 症状は術直後に生しるし，第二の場合には痔核形成の時 期によってまちまちである.これに比べ第三の場合は術 後，長期間の後に出現してくる，実際汇社会保険中央総 合病院の1980年淤ら1982年までのホワイトヘッド粘膜脱 の外来患者200名のうち，その愁訴発現時期が 判明した もの141名につき調べてみたところ，5年未満に粘膜脱 が出現したものは，41例 (30\%)，5 年以上 10 年未満 43 例 $(30 \%) ， 10$ 年以上，57例 $(40 \%)$ となっていた. 5 年未 満にその愁訴が溌生したもの41例は，おそらく第一の夕 イプの粘膜脱がほとんどであろうし，10年以上の経過の のち発生した57例は第三のタイプのものがほとんどと推 測される。

さて，第一，第二のような手術の失敗によるものは別 として第三のタイプのように手術が完全であったのに長 期間の経過の後，なぜに粘膜脱が出現してくるのかにつ いて考えてみる．肞門の支持組織としては連合縦走筋 conjoined longitudinal muscle が知られている.つまり， 直腸の縱走筋は下行し骨盤隔膜を貫く所汃ら肛門挙筋 と混合して連合縦走筋になる。これが一部は内括約笳を 歯状線のあたりで貫き歯状線直下の粘膜筋板に定着し， また一部は内括約笳の下端あたりで多数の細い線維とな って肚門上皮，肛門緣，周因皮膚化定着し，それぞれ支 持組織として働いている8). また mucosal suspensory ligament によって肛門上皮は歯状線あたりで支持され ているともいわれている゚2. いずれにせよ，このような 支持組織によって肛門上皮は肛門外一脱出することを防 がれているわけである.ところが，ホワイトヘッド手術 はこのような肚門の支持組織を全周性に破壊してしまう 術式である，乞のため，術直後は良くとも日々の排便時 にかかる肛門への負担などからしだいに粘膜脱が生じて きてしまうのである。

以上，述べてきたようにホワイトヘッド乎術後には種 々の後障害が䓯起される，そして前述したようにその後 障害のために治瘵を必要とされる例は現在でむ少なくな い. 表 1 は他院での肚門手術の後障害のため我々が行っ た手術例をまとめてみたものである１982年末までに総 計で954例の手術が行われているが，ホワイトヘッド手 術が原因で後障害をきたし，そのために手術となったも のが 470 例， $49 \%$ とほぼ半数をしめていた，そして，そ 
表 1 後障害 (手術例)

\begin{tabular}{|c|c|c|c|c|c|c|}
\hline 原因 ${ }^{\text {種類 }}$ & 狭 窄 & 粘膜脱 & $\mid$\begin{tabular}{|r} 
難 \\
治荡創
\end{tabular} & 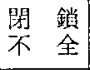 & その他 & 計 \\
\hline $\begin{array}{l}\text { Whitehead } \\
\text { 手 術 }\end{array}$ & 64 & 405 & 1 & & & 470 \\
\hline 将核手術 & 84 & 16 & 11 & 1 & & 112 \\
\hline 結森切除術 & 24 & 4 & 8 & & 2 & 38 \\
\hline 将瘦手術 & 32 & 29 & 37 & 23 & 11 & 132 \\
\hline 裂肛手術 & 10 & & 14 & & 1 & 25 \\
\hline 膚蝕療法 & 101 & & 32 & & 3 & 136 \\
\hline 結 禁 術 & 3 & & 1 & & & 4 \\
\hline その他 & 19 & 1 & 6 & 7 & 4 & 37 \\
\hline 計 & 337 & 455 & 110 & 31 & 21 & 954 \\
\hline
\end{tabular}

の内訳は粘膜脱のために手術となったものが405例， 86 $\%$ ，肛門狭窄で手術となったもの，64例，14\%であっ た. 手術にいたった後障害は，いわば重症のものといっ てよく，その中で約半数がホワイトヘッド手術が原因で あったということはホワイトヘッド手術がいかに重症な 後障害の原因となりやすい術式であるかということを現 わしているといえる. またホワイトヘッド手術の後障害 のなかで粘膜脱により手術を受けていたものがほとんど であったということは，ホワイトヘッド手術の後障害と していかに粘膜脱が多く，その治㙩が難しいかを示して いるといえる。

\section{ホワイトヘッド手術による後障害の治療}

ホワイトヘッド手術による後障害の中で，排ガス，排 便などの知覚異常は，いったん生じてしまっては 2 度と 治療のしょうのないものである. 前述したごとく、これ は肛門の知覚の場である歯状線近傍を全周性に切除して しまった結果に生じた病態のためである.

これに比べホワイトヘッド手術後の肛門狭窄の治療は 容易である. ホワイトヘッド手術後の肚門狭窄はホワイ トヘッド手術の際の粘膜皮虞縫合部が肛門管に輪状に配 列された痿痕となり肛門管の自由な㹡張を妨げる結果に 生しるものである. したがって肚門狭窄の治療は，この 輪状に配列された瘢痕の連続性を断てばよいわけであ る. 我々は軽度の狭窄であるならば肛門の $1 \sim 2$ 力所で 瘵痕の一部を切除し開放創として治しているし, 強度の 狭窄でその瘢痕の幅が広い場合には主に肛門後方で，そ して時には前方にてもその瘢痕を切除し裂肚の手術の際 飞行う皮膚弁移動術 sliding skin graft を用いて皮膚弁 をその切除部へ移動させている.

ホワイトヘッド手術後の粘膜脱の治療は粘膜脱の発生 機序，程度，および患者の愁訴などを考慮し適切な方法
が選ばれなければならない。

まず，粘膜脱が著明でなく粘膜皮䖉縫合部が肛門管内 に存在し，それょり口側の直腸粘膜に発赤を認め出血を みるものがあるが，このようなもの茂しては出血を主 訴とする内痒核に対する治療と同様でよい，つまり保存 的に治療するか外来処置として出血を主訴とする内痔核 に有効な硬化療法を行ったり赤外線凝固器102を用いて止 血操作を行ったりする.

次に初回の手術時に低位にて痩核帯を切除してしまっ たために痔核が再び形成され，そのための愁訴が主のよ うな粘膜脱に対しては将核に対する治療を行えば良い。 外来処置として McGivney 型の将核結㷊器を用いて痔 核様部分を輪ゴムで結紮したり ${ }^{11}$ ，凍結療法を行ったり する．手術としては痔核様部分に 対し 結禁切除術を行 5.

初回の手術時に皮切を外側偪置きすぎたため術直後よ り粘膜皮虐縫合部が肛門外飞露出しているような粘膜脱 に対しては，その肛門管外に存在している粘膜脱の存在 自体が愁訴の原因であるから，その露出部分に対し手術 侵襲を加えなければならない，露出している粘膜脱が 1/4 周以下の部分的なものであるならば 庨核の結禁切除 術に準じて同部を放射状に切除すればよい，半周にわた るほどの広範囲のものであるならば，この方法では切除 幅が広すぎるため困難であるので，まず粘膜脱部を環状 切除し次いで粘膜皮膚縫合を行い肚囲皮简に減張切開を 加え皮膚昪を作成し，これを肛門管内に移動させるとい ら術式，つまり粘膜脱部を肚囲皮膚にて置きかえる術式 を行う.

しかしこのような皮切が外側すぎて術直後より発生し た粘膜脱が全周性にわたるものであったり，術後，長期 間たってからの粘膜脱，つまりホワイトヘッド手術本来 の欠点である肛門の支持組織破壊のために出現した粘膜 脱であると，そしてそれには全周性のものが多いが，そ の治療は難しい。

我々はこのような全周性の高度な粘膜脱に対しては(1) 痔核の結森切除術に準じて 3 カ所ほどで余剩粘膜を放射 状に切除する方法 (以後 LE 法と略記), (2) 2 力所ほど で部分的に余剩粘膜を切除し粘膜皮膚縫合を行い皮膚弁 .を作成し肚門管内一移動させる方法(部分的 SSG 法), (3) 3 力所 LE 法を行い，その間を部分的 SSG 法で行 う方法 (LE+SSG 法) などを行ってみたことがあっ た6,12,133が完全とはいえなかった。 それでこのような高 度な粘膜脱化対しては全周性に余剩粘膜を環状切除し, 粘膜皮膚縫合を 施行した 後で減張切開を肚囲皮膚に加 え皮覻弁を肛門管内一移動させる方法（全周性 SSG

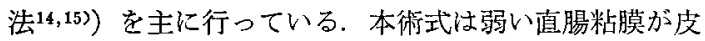


虞由来のしっかりとした肛門上皮の代りに㯰きかわった ために生ずる種々の愁訴を強い皮膚弁を肛門管内一移動 させることで防ぎ，なおかつ，この皮祽弁を肛門の支持 組織として代用し口側粘膜端の脱出を防ごうとする街式 である.

以前，我ヶはこのような高度の粘膜脱に対する各術式 の成績を比較すべく，八ガキ，電話によるアンケート調 查を行ったことがある14,15)，その結果では街後の状態が 極めて良好と答えていたものは全周性 SSG 法によるも のが最も多く，またホワイトヘッド粘膜脱に特有な症状 の術後の改善度についても全周性 SSG 法によるものが 脱出，疼痛，べとつきに関して最も良く改善されてお り，出血に対しても部分的 SSG 法に次いで良い成績で あった．ただ，全周性 SSG 法の場合は術後に何となく 肛門のしまりが悪くなったといら程度からガスが我慢で きなくなった，下淑便だと漏らしてしまらといった程度 まで種々の程度に肛門のしまりの悪さを訴えるものが約 $17 \%$ にみらた．裂肛に対し内括約觔を肛門後方にて部 分切開し sliding skin graft を行う術式においても約30 \%程度の排ガス漏れ，便漏れなどの minor incontinence がおこることがよく知られている16,17)が，全周性 SSG 法の場合も初回のホワイトヘッド手術により粘膜皮膚縫 合部には固い版痕組織が生しているため，これを剝離し つつ粘膜筒を形成していく場合にある程度の括約筋の損 傷はどうしても避けられず，したがって術後に肛門のし まりの悪さが生じることがあると考えられる．また皮膚 弁を肛門管内人全周性に移動させる術式であるため今ま での柔らかい直腸粘膜が硬い皮虐に置きかわって招り， したがって皮膚が肛門上皮の代用として馿染むまでには 時間がかかるといらこともその一因であるう。地，ア ンケート調查の結果から全周性の高度な粘膜脱に対して は一部に肛門のしまりの悪さを訴えるものがあるにせ 上，その愁訴の改善度から考えてみて全周性 SSG 法が 良いといらことが䝷えたわけである。しかし本術式の場 合、いってみれば再び初回のホワイトヘッド手術と同等 の手術侵襲を肚門に加え，しかるのち皮膚弁を肛門管内 一移動させるといら術式であるため，その手術侵襲はか なりのものとなってしまう。また10年以上の長期経過例 を経験して抢らず，したがって肛門管内に移動した皮䖉 并が長期間の経過の後も肛門の支持組織として働き粘膜 脱を防ぎうるかどうかについては今後，検討を加える必 要がある．ただし，現時点に扔いては全周性にわたる粘 膜脱の場合で，しかも初回の手術の際に全肛門は破壊さ れてしまっている場合において粘膜脱による種々の愁訴 を改善させるためには本術式は適応のある術式と考えて いる.

\section{ま と め}

ホワイトヘッド手術による後障害の病態とをの治療に ついて我々が行っている術式を中心に述べた．いったん ホワイトヘッド手術が施行されるとデリケートな肛門は 破壊さ机 人工的肛門となってしまう。をてて，ともす れば重篤な後障害を伴いやすく，その完全な修復は難し い，良性疾患である㾌核に対し，より侵襲も少なく技術 的に容易で安全な結禁切除術式が存在する今，このよう な致命的な後障害を生じるホワイトヘッド手術を行わな い上うにすることを再度, 強調したい。

\section{文献}

1) Whitehead $W$ : The surgical treatment of hemorrhoids. Br Med J $1: 148-150,1882$

2）三技純郎：Whitehead 氏手術及びその変法の 難点につ语。直腸肛門誌 $17: 29-41,1960$

3) 坂部 孝, 山中䫓正, 水野秀一ほ加: Whitehead 氏法结招ける Sliding Skin Graft の経験. 直腸肛門勍 $17: 25-28,1961$

4）隅越幸男, 河野一男, 梅原誠一ほ加：肛門疾患 手術後遗聇例の検封。大腸肛門誌 $20: 154-156$, 1965

5) Gorsch RV : Proctologic Anatomy. 2nd ed. Baltimore, The Williams \& Wilkins company, 1955, p 293-298

6）岡田光生, 传藤昭二, 平塚 襄ほか：肛門疾患 征後後遺症，特仁直腸粘膜脱㧍上び肛門忮窄に 対する Sliding Skin gratt による治療につい $\tau$. 大腸肛門誌 $24: 27-28,1971$

7）坂部 孝：痔核治療後遗症に対する Sliding Skin Graft. 大腸肛門誌 $22: 36-37,1970$

8) Gorsch RV: Proctologic Anatomy. 2nd ed. Baltimore, The Williams \& Wilkins company, 1955, p 71-77

9）荒川広太郎：痔核治療の後遗症の対策一肛門括 約笳間中㜔を中心として。大腸肛門誌 $22: 35-$ 36,1970

10）岩垂純一，隅越幸男：肛門疾患に対する外来处 圈. 外科治撩 $48: 623-631,1983$.

11）荒川健二郎：結禁器を用いた特核の結热潦法 大腸肛門誌 $25: 205-212 ， 1972$

12）佐藤昭二, 佐江正治, 神淳一ほか：ホワイト ヘッド手術後遗症の治療成績。大腸肛門誌 28 : 134,1975

13）坂田寞人，隅越幸男，岡田光生ほか：ホワイト ヘッド肛門の対策。大腸肛門誌 $31: 372-373$, 1978

14）岩堇純一，竹之下誠一，石田裕ほか：ホワイ トヘッド肛門の形成手術。大腸肛門誌 $34: 551$, 1981

15）岩垂純一，柳田 通，岡田光生はか：ホワイト ヘッド肛鬥の治療。外科治療 $45: 393-401$, 1981 
16）松田保秀，浅野てる，源辺 昇任加：肛門形成 術 (sliding skin graft) 術後の排便感賞の追跡 調查につマて. 大腸肛門誌 $28: 134-135,1975$
17）住江正治, 石田 裕, 坂田筧人ほか：肛阴形成 術後の肛門機能. 大腸肛門誌 $31: 356-357$, 1978

\title{
Pathological Condition of and Treatment for Disorders after Whitehead's Operation
}

\author{
J. Iwadare, Y. Sumikoshi, M. Okada, S. Tsukamoto, \\ K. Kawahara, R. Ono and M. Kohda \\ (Colo-proctology Center, Social Insurance Central \\ Hospital, Tokyo)
}

Disorders after Whitehead's operation include abnormalities in perception of flatus and bowel action, anal stenosis and mucosal prolapse. Abnormalities in perception of flatus and bowel action occur due to all-circumferential excision of the area near the dentate line, which is a delicary-perceptive area of the anus. Anal stenosis arises because the ring scar is formed in the area where the rectal mucosa and the skin are anastomosed after allcircumferential excision of hemorrhoids, and it prevents free dilation of the anus. Rectal prolapse appears because the supporting tissues of the anus are destroyed by Whitehead's operation or because of the failure of the operation. Abnormalities in the perception of flatus and bowel action cannot be treated. As for anal stenosis, the sliding skin graft method (S.S. G. method) is undertaken after partioal resection of the ring scar, as in the case of anal fissure. When mucosal prolapse ingolves $25 \%$ or less of the circumference of the anus, ligation and excision are employed. It is desirable that the S.S.G method after partial resection of the mucosa be used if mucosal prolapse affects half of the curcumference of the anus. And, if mucosal prolapse is observed in $100 \%$ of the circumference of the anus, the S.S.G. method is employed after all-cirumferential resection of the excess mucosa, and the results are favorable. 